\title{
XIV. Account of the new machine invented by the late Mr. Custance, for making vegetable cuttings for the microscope
}

\section{Dr. Thornton}

To cite this article: Dr. Thornton (1799) XIV. Account of the new machine invented by the late Mr. Custance, for making vegetable cuttings for the microscope, Philosophical Magazine Series 1, 3:11, 302-309, DOI: 10.1080/14786449908677000

To link to this article: http://dx.doi.org/10.1080/14786449908677000

曲 Published online: 18 May 2009.

Submit your article to this journal $[\pi$

Џll Article views: 4

Q View related articles $\sqsubset$ 
dered a feton in the neck, as the iffue was dried up. I directed alfo bark, columbo, and prepared kali, to correct acidity and brace the ftomach, as alfo to render the blood more attractive of oxygen, and the body was kept regular with aloetic pills; and this plan fpeedily produced the bleffing of found health, which has continued now upwards of fifteen months, without any difagreeable nervous fenfations, and without a fingle excurfion being made into the country.

Obfervations on this Cafe. In the cafe of Mr. Ruffel, which was melancholia, recorded by Dr. Beddoes, the cure was effected without a feton; how much are we therefore to attribute to this application in the prefent inftance? The drying up the iffue by the vital air, when employed alone, did it not denote, from the abforption of this principle, an increafed energy of the abforbents? I have before noticed, that where ferum was difcharged, this has happened; but when matter is fecreted, there is on the contrary a more abundant difcharge, or the ferum is converted into laudable pus. In the cafe of Mr. Fixfen, St. Anne's-Street, Weftminfter, an iffue which could not be made to difcharge, began immediately to pour out matter, upon the commencement of the inhalation of the medicinal air. The varicofe veins difappearing was a ftrong mark of increafed energy in the circulating veffels. The numbnefs of the fingers going off, thewed increafed action remote from the heart; the glow, the increafe of fpirits, all declare in marked expreffions the influence of vital air; and what makes me the more inclined to this opinion is, that country air before ufed to afford the only relief.

XIV. Account of the New Macbine invented by the late Mr. Custance, for making Vegetable Cuttings for the Microfcope. Communicated by Dr. Thовмтом, Lecturer on Medical Botany at Guy's Hopital, Eंc. \&ंc.

THE firf idea of making vegetable cuttings to be examined by the microfcope, originated from the famous 
Dr. Hooke above a century ago, as may be feen in his Micrographia.

"Charcoal, or a vegetable burnt black," fays this eminent philofopher, "affords an object no lefs pleafant than inAructive; for if you take a fmall round piece of charcoal, and break it hort with your fingers, you may perceive it to break with a very fmooth and fleek furface, almoft like the furface of black fealing wax : this furface, if it be looked on with an ordinary microfcope, does manifeft abundance of thofe pores, which are alfo vifible to the eye in many kinds of wood, ranged round the pith, both in a kind of circular order, and a radiant one. Of thefe there are a multitude in the fubftance of the coal, every where almoft perforating and drilling it from end to end; by means of which, be the coal ever fo long, you may eafily blow through it; and this you may prefently find, by wetting one end of it with fpittle, and blowing at the other.

"But this is not all: for, befides thofe many great and confpicuous irregular fpots or pores, if a better microfcope be made ufe of, there will appear an infinite company of exceedingly fmall and very regular pores, -fo thick and fo orderly fet, and fo clofe to one another, that they leave very little room or fpace between them to be filled with a folid body; for the apparent interftitia, or feparating fides of thefe pores, feem fo thin in fome places, that the texture of a honeycomb cannot be more porous : though this be not every where fo, the intercurrent partitions in fome places being very much thicker in proportion to the holes.

" Moft of thefe fmall pores feemed to be pretty round, and were ranged in rows that radiated from the pith to the bark; they all of them feemed to be continued open pores, running the whole length of the ftick; and that they were all perforated, I tried by breaking off a very thin fliver of the coal crofs-ways, and then with my microfcope diligently furveying them againft the light, for by that means I was able to fee quite through them. 
"Thefe pores were fo exceedingly fmall and thick, that in a line of them, $\frac{r}{r}$ part of an inch long, I found, by numbering them, no lefs than 50 fmall pores; and therefore, in a line of them an inch long, muft be no lefs than 2700 pores; and in a circular area of an inch diameter, muft be about $5,725,35^{\circ}$ of the like pores; fo that a ftick of an inch diameter may containe no lefs than feven hundred and twenty-five thoufand, befides 5 millions of pores, which would, I doubt not, feem even incredible, were not every one left to believe his own eyes. Nay, having fince examined cocus, black and green ebony, lignum vitæ, \&c. I found that all thefe woods have their pores abundantly fmaller than thofe of foft light wood; in fo much that thofe of guajacum feemed not above an eighth part of the bignefs of the pores of bech, but then the interftitia were thicker; fo prodigiouffy curious are the contrivances, pipes, or fuces by which the fuccus nutritius, or juyce of a vegetable, is conveyed from place to place." He afterwards fays, "I took a gocd clear piece of cork, and, with a pen-kuife harpened as keen as a razor, I cut a piece of it off, and thereby left the furface of it exceeding fmooth; then examining it very diligently with a microfcope; methought I could perceive it to appear a little porous; but I could not fo plainly diftinguifh them as to be fure that they were pores, much lefs what figure they were of: but judging from the lightnefs and yidling quality of the cork, that certainly the texture could not be fo curions, but that poffibly, if I could ufe forme further diligence, I might find it to be difcernible with a microfcope, I, with the fame fharp pen-knife, cut off from the former fmooth furface an exceeding thin piece of it; and placing it on a black object plate, becaufe it was itfelf a white body, and cafting the light on it with a deep plano-convex glafs, I could exceeding plainly perceive it to be all perforated and porous, much like a honey-comb, but that the pores of it were not regular; yet it was not unlike a honey-comb in thefe particulars." 
This is the firft rude hint refpecting the mode of cutting of vegetables, fince which time cutting machines have been contrived by feveral ingenious mechanics, that might better perform this delicate operation. In $1770 \mathrm{Dr}$. Hill publined a treatife, in which he explained the conftruction of timber by means of vegetable cuttings examined by the microfcope; and he in that work gives an account of a cutting engine, in which a fpiral knife is employed; the invention, he fays, of Mr. Cummings. The late Mr. Adams, optician in Fleetftreet, appears to have contrived a machine for cutting thin fections of wood, in order that the texture thereof might be more vifible to the microfcope; and in his Effays on the Microfcope, he fays, that this his invention was afterwards improved by Mr. Cummings. Notwithftanding the application of Dr. Mill, and of others who attempted to bring this art to perfection, Cuftance, a common carpenter from Ipfwich, furpafied every other, and, as Mr. Adams juftly obferved, continued unrivalled in his dexterity of preparing thin fections of wood, having brought this art to the higheft perfection. He cautiouny kept his method a fecret from every one, and various conjectures were made in what way he accomplifhed his unrivalled cuttings. When he was alive, I offered him fifty pounds for the difcovery, to difclofe it to the world for the promotion of fcience, and in order the better to accomplin my views in my New Illuftration of Linnæus, where the organifation of vegetables is a particular object of confideration *. When preffed, he offered me the difcovery for an hundred guineas, which thinking exorbitant, I gave up all thoughts of it; but, foon after dying, he left in his will, that every thing he poffeffed thould be put up to public auction; and, among other things, his invention of the cutting engine was particularly noticed in the catalogue. They were not, however, expofed to examination, but I did not fail being at the fale to embrace this opportinity of bidding for the two engines, fearful that a moWork.

* Reprefertations of all the Cuttings of Cuftance will be given in $t$. Is

Vor. III。 
nopoly might be made of the art of preparing vegetable cut tings, as had been fuccefsfully done by Cuftance. Although the oppofition was ftrong, I was the fuccefsful bidder, and became poffeffed of both engines, which are conftructed nearly upon the fame principle; and I am happy to embrace the prefent opportunity of communicating to the public fo valuable an acquifition to philofophy and fience.

\section{Cuflance's beft Cutting Engine defcribed.}

Fig. 1. reprefents a view, and fig. 2. a fection, of the cutting machine. It has the appearance of an oblong box, and the fidss from the bottom A (fig. 2.) up to B are made of brafs. A piece of hard mahogany, C C, is fitted into the brafs box, and fills the whole cavity down to $a$ a, leaving a void fpace at the bottom, of fufficient fize to admit the parts of the machine which work there, and which are defcribed below. From the top to the bottom of the wood there is a perforation, of which the ontline of fig. 3 . may be confidered as reprefenting a horizontal fection, which receives eafly a brafs focket, fig. 3 , in which the wood $(b)$ to be cut is fecured in its place by means of a brafs holdfaft $c$, grooved like a float fle, and preffed againft the wood by the fcrew $d$. This focket, with the holdfaft, (which viewed in front has a fluted appearance) and the piece of wood is reprefented in its place D, fig. I and 2, where it is fecured from thaking by means of the piece $e$, fig. 2, preffed againft it by the forew $f$, but not fo tight as to prevent its being raifed when required by the micrometer fcrew to be yet defcribed. The focket, which fills the perforation from the furface $\mathrm{D}$ down to $g$, has a horizontal divifion at $b$, which ferves as a bottom for the holdfaft to reft on; the cavity of the focketbelow $b$ receives a piece of metal $i$, , of which fig. 4 , is an horizontal fection; through this piece, which moves eafily up or down in the focket, is a female fcrew, in which the micrometer forew turns, which may be feen paffing through $i i$ in fig. 2. The micrometer forew, the neck of which work's in a plate $m m$, made faft to the bottom of the piece of mahogany before defcribed by means of the 
crews $n n$, is prevented from rifing or falling, when turned round, by a conical thoulder fitted into the upper fide of the plate $m m$, as may be feen in the figure, and by the micrometer index wheel o o made faft to that end of the fcrew which projects through the lower furface of $m \mathrm{~m}$. Therefore, when the index is turned, the forew wrorking in $i$ raifes or lowers $i$; the latter by its form being prevented from turning with the motion of the forew. The piece $i$, being thus raifed as much as the intended thicknefs of the flip to be cut, preffes asitrifes againt the divifion $b$, and by that means makes the brafs focket, in which the wood is made falt as before defcribed, to rife exactly the fame quantity - care being taken to regulate the preffure communicated by the fide forew $f$ in fuch a manner as juft to allow free action to the micrometer fcrew, and yet to prevent any lateral deviation in the afcent of the focket. A portion of the index wheel comes through the front of the machine (o, fig. x.); and all that is neceffary to raife the wood, the parts being previoufly adjufted in the manner defcribed, is to lay hold of the lsnob that prefents itfelf at the opening, and move it to the left, a half, a whole, or two divifions, according to the thicknefs the flip is withed to be cut. Thefe divifions are marked on the circumference of the index, and you note the quantity that paffes a ftationary point marked over the centre of the opening.

The cutting apparatus is conftructed in the following manner :-On the further edge of the upper furface of the box, a flat rule, G G, fig. $x$, made of fteel, is faftened down by the fcrews $k k$ : it is more than an eighth of an inch in thicknefs, and the front edge of it is ground perfectly ftraight, and ftands at a right angle to the furface on which it refts。 Another flat rule, one end of which, $\mathrm{H}$, may be feen projecting paft the end of $\mathrm{G}$ towards the left, ferves as a bed for the cutting knife $r r$, which is made faft to the rule by the ferews $s s$. The upper and under furface of this rule are ground parallel to each other, and its back edge is ground ftraight to 
it againft the front edge of the rule $\mathrm{G} G$. The rule $\mathrm{H}_{\text {, }}$ which is moveable with the knife $r$, is tapered from the end $H$, fo as to be fomewhat narrower at the end next to the cavity $\mathrm{D}$, than the diameter of the pieces of wood that can be contained betwixt the holdfaft $(c, f g .3$.$) and the other fide of$ the focket. From this the wonderful fimplicity and accuracy of the process, as performed by this apparatus, mutt be obvious; for the focket, or in other words the piece of wood from which the flip is to be cut, being raifed to the defired height by turning the micrometer $a$, all that is neceflary is to flide the rule $H$, with an even hand and preflure, along: between the rule $\mathrm{G} G$ and the wood to be cut ; the taper form of the knife, or rather of its bed, caufing it to thave off, as the broad end comes nearer to the focket, a flip from the furface expoled to its action. It fhould be here remarked, that a portion of the bed (the rule $H$ ) is cut away from under the knife, from $r$ to $r$, to allow the knife to pafs freely over the wood as it performs its office. To kecp the wood perfectly falt in its place while the lip is cutting of, befides the holdfant in the focket already defcribed, there is the following contrivance:-A brafs fpur, $u$, a little thinier than the rule $H$, having a circular notch at its wideft end, which may be moved or made faft at pleafure by means of the forew $v$, is brought up tight againft the wood to be cut (the wood being embraced by the circular notch), and then ferewed faft; the opening at the narrow end of the fpur, through which the fcrew paffes, is in the form of a llit, to allow it to be adapted with eafe to different fizes.

As the brafs focket riles as well as the wood, (and this is indifpenfible to fecure the parallel rifing of the wood after each cut,) it muft be obvious, that when, by being raifed to allow taking off repeated cuttings, it has been brought almoft to the knife, the apparatus mult be re-adjufted, and the wood raifed in the focket before more cuttings be taken off.

It need hardly be remarked, that the cutting knife is ground 
ground to a perfect true and fine edge, without warp or bend, that it may move through a perfect plane. 'T he accuracy and delicacy with which it works may be judged by fig. 5, which reprefents a microfcopic view of a cutting made from fo fragile a fubftance as a piece of cbarcoal.

XV. Remarkable Infance of a Turkey Cock batcbing Eggs. By M. Oedmann. From New Tranfactions of the Academy of Sciences at Stockholm. Vol. $X$.

M

ALE fowls, which affociate with a plurality of females, care fo little for their pofterity, particularly in a wild ftate, that they do not feem to have the leaft affinity to the young when hatched, and contribute neither towards rearing nor protecting them; on this account $M$. Oedmann confiders the following circumftance to be very fingular; fuch, perhaps, as was never before obferved. In the month of May I789 a turkey-hen was fitting upon eggs, and as the cock, in his folitude, began to be uneafy and to feem dejected, he was allowed to remain in the fame place along with her. $\mathrm{He}$ immediately fat down by the female, and people at firft belicved that this was only a piece of gallantry; but they foon found that he had taken fome of the eggs from under the hen, which he covered very carefully with his body. The maid, who looked after the poultry, thought this mode of hatching would be attended with little advantage, and therefore put the eggs back under the hen; but the cock was no fooner at liberty than he again carried forne of them away as before. M. Hafelhuhn, the proprietor, when be obferved this, refolved, for the fake of experiment, to let the cock have his own way, and he caufed a neft to be prepared with as many eggs as the animal's large body was able to cover. The cock feemed to be highly pleafed with this mark of confidence, fat with great patience on the eggs, and was fo attentive to the care of hatching them that he fcarcely took time to go in fearch of 